\title{
The Effect of E-Learning Sessions on the Development of Reading Comprehension: A Case of EFL Students' Perceptions at Saudi Electronic University
}

\author{
Mohammad H. Alhumsi ${ }^{1}$ \\ Rasha A. Alshaye ${ }^{2}$ (D) \\ Kholod K. Sendi ${ }^{3}$ (iD)
}

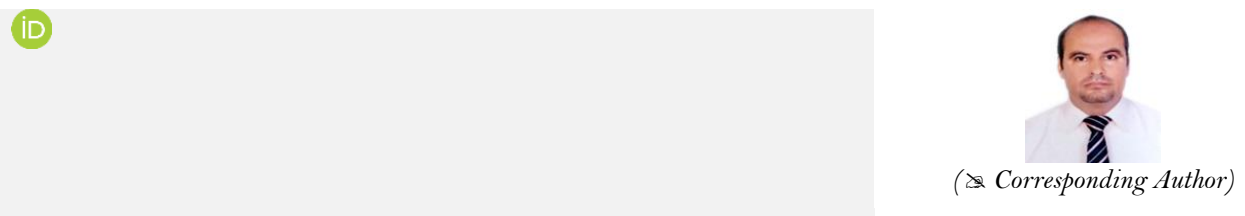

${ }_{1.2,3}$ Department of English Language and Translation, Saudi Electronic University, Saudi Arabia. 'Email:1Husam101010@gmail.com Tel: +966533649745

Email: R.alshaye@seu.edu.sa Tel: +966550747414.

Email: Kha.sendi@seu.edu.sa Tel: +966568777077

\section{Abstract}

This study investigated Saudi EFL university students' perceptions toward the development of reading comprehension through e-learning sessions. A cross-sectional questionnaire was utilized and distributed to a sample of 140 participants at Saudi Electronic University. Descriptive statistics, independent sample paired t-test and one-way ANOVA were used to analyze the data. The findings revealed that EFL university students had positive perceptions of the use of online sessions to practice the reading comprehension skill. The majority agreed that reading comprehension strategies such as skimming and scanning were more appropriate to online sessions. E-learning helped these students to be more motivated and created an atmosphere conducive to independent learning. The participants appreciated the role of online sessions in enhancing their reading comprehension skills and facilitating the level of difficulty of any reading passage. Significant differences were identified relating to the respondents' gender and academic year. Female students were more satisfied with e-learning than male students. It is recommended that in light of the rapid growth of e-learning in Saudi Arabia, educational institutions should provide online learning programs and develop well-structured courses for e-learning implementation.

Keywords: EFL University students, E-Learning, Reading comprehension, EFL students' perceptions, Online sessions, Saudi electronic university.

Citation | Mohammad H. Alhumsi; Rasha A. Alshaye; Kholod K. Sendi (2021). The Effect of E-Learning Sessions on the Development of Reading Comprehension: A Case of EFL Students Perceptions at Saudi Electronic University. Journal of Education and e-Learning Research, 8(4): 431-439.

\section{History:}

Received: 2 November 2021

Revised: 5 December 2021

Accepted: 16 December 2021

Published: 27 December 2021

Licensed: This work is licensed under a Creative Commons

Attribution 3.0 License $(\mathrm{cc})$ E

Publisher: Asian Online Journal Publishing Group
Acknowledgement: The authors extend their appreciation to the Deputyship for Research \& Innovation, Ministry of Education in Saudi Arabia for funding this research through project number 7971 .

Funding: This research work is funded by the Deputyship for Research \& Innovation, Ministry of Education in Saudi Arabia through the project number 7971.

Competing Interests: The authors declare that they have no conflict of interests.

Transparency: The authors confirm that the manuscript is an honest, accurate, and transparent account of the study was reported; that no vital features of the study have been omitted; and that any discrepancies from the study as planned have been explained.

Ethical: This study follows all ethical practices during writing.

\section{Contents}

1. Introduction

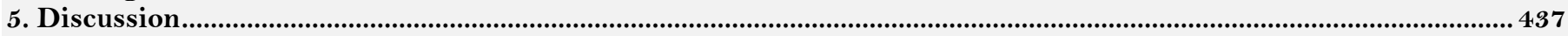

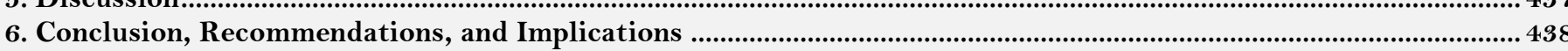

References... 


\section{Contribution of this paper to the literature}

This study contributes to the existing literature by confirming that e-learning helps students feel more motivated and creates an independent learning environment. Statistically significant differences in terms of academic status and gender were identified in favor of female students and upperclassmen. Online sessions enhance students' reading comprehension skills as well as facilitating the level of difficulty of reading passages in the Saudi context.

\section{Introduction}

The impact of information and instructional technologies on teaching and learning has been increasing dramatically in the Kingdom of Saudi Arabia (KSA). One form of such technology is the current trend towards elearning, which has shown academic benefits in this new environment (Al-Asmari \& Khan, 2014). To satisfy the $21^{\text {st }}$ century's learning and teaching requirements, the domain of electronic learning (e-learning, hereafter) inevitably involves online learning and teaching approaches based on the use of digital learning devices (Larkin, 2010). Sun, Tsai, Finger, Chen, and Yeh (2008) pointed out that "e-Learning is the use of telecommunication technology to deliver information for education and training. With the progress of information and communication technology development, e-Learning is emerging as the paradigm of modern education" (p. 1183). The successful expansion of new trend sees students' courses being implemented through the use of technology, strengthening students' critical thinking skills as well as boosting the quality of effective instruction (Caner, 2012). This paper will address the delivery of reading comprehension courses through e-learning sessions.

The previous literature has revealed a need for proactive teaching strategies that can enhance the development of reading skills in a technological environment. This issue has prompted researchers to explore e-learning processes, particularly instructional approaches such blended learning in EFL contexts, for the sake of improving the learning and teaching of reading skills (Behjat, Yamini, \& Bagheri, 2012; Yang, 2012; Zahedi \& Tabatabaei, 2015). However, although a growing number of studies on e-learning has been conducted in the Saudi Arabian context, few studies have focused on students' perceptions of e-learning in Saudi Arabia (Alkhalaf, Nguyen, Nguyen, \& Drew, 2013; Alubthne, 2018) and, more specifically, in the EFL field (Mutambik, 2018). To our best knowledge, no study has previously been conducted to examine Saudi students' perceptions of their EFL reading comprehension development through e-learning in Saudi Arabia.

Hence, the purpose of this paper is to investigate Saudi EFL university students' perceptions toward reading comprehension development during e-learning sessions.

Specifically, the research questions are as follows:

1. What are the students' perceptions of reading comprehension development during e-learning sessions?

2. What are the differences in EFL university students' perceptions of reading comprehension development during e-learning sessions in terms of their gender and academic year?

\section{Literature Review}

\subsection{E-Learning}

Rapid technological advancements have had a significant impact on education, and specifically on language learning. As a product of technology, e-learning is considered a new paradigm of modern education in the $21^{\text {st }}$ century that has transformed traditional learning and teaching methods to more innovative ones (Dwiastuty, Susilawati, \& Sulhan, 2018; Sun et al., 2008). Reflecting this trend, the literature on e-learning is extensive (Alsayyar \& Almakki, 2021). Therefore, it is difficult to find a single consistent definition of the term that all scholars agree upon (Rodrigues, Almeida, Figueiredo, \& Lopes, 2019). Different scholars have defined e-learning in different ways, but a basic definition of e-learning is offered by Rodrigues et al. (2019), who stated that "e-learning is an innovative web-based system based on digital technologies and other forms of educational materials whose primary goal is to provide students with a personalized, learner-centered, open, enjoyable and interactive learning environment supporting and enhancing the learning processes" (p. 95).

Throughout the literature, many different terms are used to refer to e-learning, such as online learning, webbased learning, distance learning, computerized-learning and virtual learning. These terms are sometimes used interchangeably because they all refer to the use of electronic technologies for the purpose of learning (Flórez, Pineda, \& Marín, 2012; Muñoz \& González, 2010; Valverde-Berrocoso, Garrido-Arroyo, Burgos-Videla, \& Morales-Cevallos, 2020). However, Rodrigues et al. (2019) rightly argued that although some scholars consider elearning to be a new version or extension of distance learning, e-learning and distance learning are not synonymous terms. In addition, e-learning differs from blended learning, which refers to the process of combining traditional face-to-face learning with online learning (Anas, 2020; Radia, 2019; Valverde-Berrocoso et al., 2020).

Finally, e-learning is a powerful educational tool. It reduces the costs of education (Valverde-Berrocoso et al., 2020) and offers students the flexibility and convenience of attending classes anywhere and at any time (Alhumsi \& Alshaye, 2021; Gawad \& Al-Masaud, 2014). The growing importance of e-learning has a great impact on the global academic environment. In line with this global trend, e-learning in Saudi Arabia has witnessed significant growth. The next section focuses on the development of e-learning in Saudi higher education.

\subsection{E-Learning in Saudi Arabia}

E-learning was first adopted in Saudi Arabia in the early 1990s and its use was further reinforced in the following decades to support the country's growing university student population (Aljaber, 2018). The Ministry of Higher Education (MOHE) initiated the Computer and Information Center in 1996. This center offers a set of services related to information and communication technologies to assist educational institutions (Al-Asmari \& Khan, 2014). In 2000, MOHE created a notable computer project, involving all educational institutions in KSA, for the purpose of initiating modern curricula, as well as cultivating instructors and students' abilities (Oyaid, 2009). Critically, KSA has launched its National Plan for Information Technology to enable people to get more involved in e-learning, thereby promoting lifelong education. This act has encouraged and supported the application of e- 
learning in academic institutions. For example, the National Center for E-Learning and Distance Learning in Riyadh was founded in 2005 (Mirza, 2007). Thus, this new learning domain has imposed itself on all aspects of educational institutions, requiring remarkable technical skills to rapidly meet the technological challenges (AlAsmari \& Khan, 2014). To promote improved technical skills, the government of KSA has been responsible for offering technical education and vocational training. It is important to note that the government's Organization for Technical Education and Vocational Training (GOTEVOT) launched a Centre for E-Learning Training and Resources in 2002. This organization offers an e-library of more than 50,000 books. It also provides 3,000 training programs offering services to the community as well as promoting lifelong learning (Al-Khalifa, 2010). Additionally, memorandums of understanding were signed between MOHE and Microsoft and Intel to create elearning programs and instructional training programs for teachers and students (Al-Asmari \& Khan, 2014). In short, KSA is considered the largest information and communication technology market in the Middle East.

As for e-learning in Saudi Higher Education, the focus on e-learning has dramatically increased in the majority of Saudi universities. Entire curricula have been replaced by e-learning materials (Al-Khalifa, 2010). Such universities include King Saud University, King Abdul Aziz University, King Khalid University, Taiba University, Al-Baha University, Qassim University, and Madinah Islamic University. These universities have signed formal agreements with the NCeDL to provide e-learning programs in their curricula. Another example is the e-Learning Centre, established in 2003, in the Academic Development Deanship at King Fahad University of Petroleum and Minerals. This particular center has introduced integrated access to online resources through the use of WebCT (Al-Asmari \& Khan, 2014).

\subsubsection{Prior Studies on E-Learning in Saudi Arabia}

As a result of the COVID-19 pandemic, most education systems have shifted to online learning. The shift from traditional learning to online learning "showed the strengths and weaknesses of education systems facing the challenge of digitalization" (Valverde-Berrocoso et al., 2020). According to Oraif and Elyas (2021), higher education in Saudi Arabia has proved its effectiveness during this period of the pandemic. A complete shift to elearning can impact students' learning behaviors. Therefore, Oraif and Elyas (2021) investigated learners' level of engagement in an online EFL course during the pandemic in Saudi Arabia. The researchers surveyed 379 female students. Their findings showed a high level of engagement among the participants. The researchers argued that COVID-19 has emphasized the usefulness and the importance of e-learning worldwide.

It is interesting to note that e-learning in KSA has a robust position in the literature; several studies have tackled the issue of e-learning (Al-Asmari \& Khan, 2014; Al-Harbi, 2011; Al-Nuaim, 2012; Alkhalaf, Drew, \& Alhussain, 2012; Oyaid, 2009). According to Yamani (2014), despite the rapid expansion of e-learning in Saudi Arabia, the implementation of successful e-learning in the Saudi educational system is still limited. Naveed, Muhammed, Sanober, Qureshi, and Shah (2017) investigated the various barriers that can affect the successful adoption and implementation of e-learning in Saudi Universities. The researchers used a survey to collect data from 257 respondents, including university students, instructors, and e-learning staff from different Saudi universities. The researchers found that barriers relating to infrastructure and technology are the most significant factors affecting the e-learning system in Saudi universities. Similarly, Algahtani (2011) examined the effectiveness of e-learning through a questionnaire distributed to 300 male learners and a focus group interview at King Saud University and Imam University in Saudi Arabia. The study showed that students appreciated their e-learning experience. They were motivated by the interactive nature of e-learning and were able to learn autonomously. On the other hand, the participants reported some barriers related to infrastructural weaknesses and a lack of acceptance of e-learning.

In addition, Gawad and Al-Masaud (2014) presented some factors that affected the successful application of elearning at Qassim University by surveying 100 male faculty members and undergraduate students. The study indicated that the two limiting factors that affected e-learning were financial support to obtain "advanced PC's, labs, and establishing strong computer network" (p.12) and the lack of English language proficiency on the part of some faculty members and students. Another study, conducted by Al-Nuaim (2012), compared students' performance in face-to-face classrooms with the performance of students who studied the same course with the same instructor in virtual classrooms. The findings showed no significant difference in the performance of the two groups.

Focusing on blended learning (BL), Anas (2020) cited some studies revealing that Saudi students have positive attitudes towards BL, and the academic performance of students is better in blended learning environments than in the traditional learning environment. Anas (2020) used a mixed-method study to discover students' perceptions and preferences towards BL at the University of Bisha. The researcher focused on three components of BL: multimedia learning materials, assessment, and interactive activities. The findings indicated that audio materials, descriptive text materials to video, plain text, and embedded communication tools were favored by students.

A growing number of studies has been published on e-learning in Saudi Arabian context. However, few studies have been conducted on students' perceptions of e-learning in Saudi Arabia (Alkhalaf et al., 2013; Alubthne, 2018). One study conducted by Al-Fahad (2010) explored learners' satisfaction with the e-learning implemented at King Saud University. The researcher distributed questionnaires to 201 female students. Al-Fahad (2010) found that students had positive views toward e-learning as a teaching tool, and they believed that e-learning offers more benefits than traditional learning.

In addition, Alkhalaf et al. (2013) conducted a mixed-methods study to examine learners' satisfaction and collaborative learning at two Saudi universities: King Saud University and Qassim University. The researchers found that students were not unhappy with the information technology infrastructure. On the contrary, students were satisfied with the availability of collaboration tools such as discussion boards. However, students reported that they were not required to collaborate with other students, which resulted in a low level of interaction. The researchers recommended that collaborative learning be fostered and encouraged by instructors to increase student interaction. Another mixed method study, conducted by Alubthne (2018), identified students' perspectives on the quality elements required for online courses at the Saudi Electronic University. The study revealed that some of 
the crucial factors include meaningful interactions among students, interaction with instructors using different communication methods, pointing out course objectives, relating course content to real world applications, and using summaries and timelines.

In terms of gender, the literature shows that gender has a great impact on students' attitudes towards elearning. Liaw and Huang (2011) confirmed that several studies have indicated that male students have more positive attitudes toward e-learning than female students. Similarly, in their quantitative study, Zabadi and AlAlawi (2016) examined 371 students' attitudes toward e-learning at the University of Business \& Technology (UBT). The study showed that students had an overall positive attitude toward e-learning, but that their attitudes varied based on their gender, technology usage and skills. The researchers concluded that male students had more positive attitudes than female students. In addition, Alkhalaf et al. (2013) argued that "female students tend to feel less confident and comfortable with using e-learning technology in general and with collaboration-enabling technology in particular" (p. 72). In contrast, Sebnmen (2015) found that female students had more positive attitudes toward e-learning than their male counterparts. On the other hand, Suri and Sharma (2013) claimed that "no significant relationship exists between gender and attitude towards computer and e-learning" (p. 132). Alubthne (2018) also found no significant differences among students' perspectives about online courses that could be explained by their age or gender. Finally, several studies have shown a positive correlation between technology usage/familiarity of university students with e-learning and attitudes toward e-learning (Zabadi \& Al-Alawi, 2016).

Regarding English language teaching and learning, it has been proven that e-learning can be an effective strategy for teaching the English language (Behjat et al., 2012; Saeheng, 2017). Students can benefit from elearning resources to improve the four main English language skills: listening, speaking, reading, and writing (Mutambik, 2018). According to Farooq and Javid (2012), second/foreign language learning through e-learning is better than traditional classroom learning in the age of technology.

Although there are numerous studies on the role of e-learning in the EFL field, few studies have been conducted in the Saudi context (Mutambik, 2018). In their quantitative study, Farooq and Javid (2012) examined the influence of e-learning on motivating students to learn English as a foreign language at Taif University. The researchers concluded that although the majority of the students had access to the internet, they were not motivated to use technology in their learning. The students believed that the curriculum should be better integrated with technology. The study suggested that teachers who are reluctant to use technological tools have to be trained to incorporate technology in the curriculum to create a better learning environment for students.

Mutambik's (2018) qualitative research focused on the perceptions of students and instructors towards the role of e-learning in studying EFL in Saudi Arabia. The participants had a positive attitude toward e-learning as a tool to improve their English language skills and to promote independent, flexible and collaborative learning. Another study by Al-Mubireek (2019) explored students' attitudes towards two e-learning platforms (Blackboard and Oxford IQ Online) used by 1364 students at Imam Abdulrahman Bin Faisal University (IAU). Their results showed that students had a positive attitude toward these e-learning platforms. Students believed that incorporating e-learning helped them to improve their English.

\subsection{The Saudi Electronic University}

The Saudi Electronic University (SEU) was established in 2011 through collaboration with international universities such as Walden University, the University of Phoenix and Franklin University. It is "the only specialized university in distance education in the Kingdom of Saudi Arabia that offers both graduate and undergraduate degree programs along with life-long education" (Saudi Electronic University [SEU], 2021, para. 1). The university is located in Riyadh and has several local centers in different regions of Saudi Arabia. The SEU implements blended learning by combining online and face-to-face education. The objectives of the SEU include "making education more flexible, promoting communication and cooperation between faculty members, and enabling students limited by their location and jobs to pursue further education and specialise in postgraduate studies" (Aljaber, 2018). Similar to most Saudi universities, the SEU is segregated by gender.

\subsection{Reading Comprehension in a Foreign Language}

Reading in a foreign language has been defined as a process involving both the text and the reader. In this process, multiple kinds of language awareness and background knowledge (Alhumsi, 2021) interact with the information in the text. This leads to text comprehension (Dubin \& Bycina, 1991). Another researcher has described reading comprehension as an interactive process involving both the text and the reader which leads to reading fluency to elicit the meaning (Alyousef, 2005). The same researcher introduced six knowledge areas and skills required for reading comprehension. These involve the knowledge of formal discourse structure, automatic recognition skills, content/world background knowledge, vocabulary and structural knowledge, synthesis and evaluation strategies, and metacognitive knowledge (Alyousef, 2005). As for skilled readers, Grabe and Stoller (2002) suggested two different processes, including lower-level processes, related to grammar recognition and vocabulary when reading, and higher-level processes, related to the interpretation of a text, schemata, and comprehension. These researchers argued that a combination of lower- and higher-level processes is probably needed by a fluent reader to gain reliable and effective reading skills (Grabe \& Stoller, 2002).

\subsection{Reading Comprehension and E-Learning}

E-learning platforms are increasingly used by ESL and EFL students. Zarei and Amani (2018) explored the effects of different online tools (word reference lists, media, and vocabulary games) on reading and vocabulary comprehension. The researchers pointed out that using a single online tool to teach second language learners may not lead to the desired outcome. Different online tools have different effects on language learning. Therefore, teachers have to use a combination of these tools to achieve the desired learning outcome. Similarly, in their qualitative study, Dwiastuty et al. (2018) proved that the use of Readutainment (entertaining reading activities) as an e-learning activity improved learners' reading comprehension skill and helped them to enrich their English vocabulary. 
In terms of web-based/online courses, Muñoz and González's (2010) case study discussed the impact of webbased learning on EFL reading comprehension. The researchers focused on the roles teachers play in this learning environment. According to Muñoz and González (2010), teachers in web-based learning environments play new roles, namely those of "solving technical problems, providing immediate feedback, interacting with students in a non-traditional way, providing time management advice, and acting as a constant motivator" (p. 69). Therefore, the researchers recommended that teachers be trained to play these roles to teach English effectively. Flórez et al. (2012) conducted another case study that shed light on reading comprehension within a web-based learning environment. The researchers examined students' perceptions of a web-based English reading comprehension course. Their results showed that students expressed a positive attitude toward the inclusion of video tutorials and the use of online communication tools such as emails, chats and forums. These tools enabled students to have an effective means of communication with their teacher. Also, students explained that web-based education helped them save time and money because they did have to travel to attend classes.

In the blended learning context (that combines traditional face-to-face instruction with online instruction), Radia (2019) investigated students' attitudes toward the main characteristics of blended learning in a reading comprehension course. Students displayed an overall positive attitude toward blended learning. Similar to the previous studies cited in this section, the researcher reported that students' reading skills improved. Blended learning helped to increase students' motivation and responsibility for their learning experience. In addition, Behjat et al. (2012) explored whether traditional or blended learning environments were more effective at enhancing the reading comprehension of university EFL learners. The findings of this quantitative study showed that blended learning helped the participants to perform better in their reading comprehension. Finally, Saeheng (2017) examined learners' satisfaction with three different teaching methods on a reading comprehension course: elearning, blended learning, and traditional learning. The researcher used qualitative and quantitative methods to collect data. The study concluded that the participants were satisfied with e-learning and blended learning. According to Saeheng (2017), motivation and autonomy are two important factors that affect students' success in reading comprehension. The researcher found that these two teaching methods (e-learning and blended learning) motivated students to practice their English reading comprehension skills.

\subsection{The Theory of Online Collaborative Learning (OCL)}

Picciano (2017) argued that many theories have been gradually developed describing the acceptability of online environments. One of these theories is Online Collaborative Learning (OCL). OCL is a theory suggested by Harasim (2012) that highlights the possibilities of the Internet to offer learning environments that encourage knowledge building and collaboration. According to Harasim (2012) this theory represents "a new theory of learning that focuses on collaborative learning, knowledge building, and Internet use as a means to reshape formal, non-formal, and informal education for the Knowledge Age” (p. 81). In addition, Harasim (2012) contended that the advantages of shifting teaching and learning to the online environment are significant and noticeable.

\section{Methodology}

\subsection{Research Design}

This paper employed a quantitative method. Creswell (2012) stated that this method relates to numeric data collection and its statistical analysis. To collect data, this research used a cross-sectional questionnaire to identify EFL students' perceptions of the effect of e-learning sessions on their reading comprehension development. Data collection was conducted during the second semester of the 2020/2021 academic year. SPSS software version 22 was utilized for the process of analysis.

\subsection{Participants}

In order to identify EFL students' perceptions of the effect of e-learning sessions on reading comprehension development at the Saudi Electronic University, 140 undergraduate students (42 males and 98 females) were recruited to participate in this study. Their academic year ranged from level (3\&4) to level (7\&8). As for their occupation status, 80 of them were both working and studying, whereas 60 of them were considered full-time students. It should be noted that all participants majoring in English Language and Translation experience elearning sessions during their course of study. Table 1 describes the demographic characteristics of the participants.

Table-1. Demographic characteristics of the participants.

\begin{tabular}{|c|c|c|}
\hline Item & Frequency & Percentage \\
\hline \multicolumn{3}{|c|}{ Student's Academic Year } \\
\hline Freshman (level 3\&4) & 100 & $71.4 \%$ \\
\hline Junior (level 5\&6) & 30 & $21.4 \%$ \\
\hline Senior (level 7\&8) & 10 & $7.2 \%$ \\
\hline Total & 140 & $100 \%$ \\
\hline \multicolumn{3}{|l|}{ Occupation Status } \\
\hline Working & 80 & $57.1 \%$ \\
\hline Full- time student & 60 & $42.9 \%$ \\
\hline Total & 140 & $100 \%$ \\
\hline \multicolumn{3}{|l|}{ Gender } \\
\hline Male & 42 & $30.0 \%$ \\
\hline Female & 98 & $70.0 \%$ \\
\hline Total & 140 & $100 \%$ \\
\hline
\end{tabular}




\subsection{Instrument and Research Procedure}

This study used a cross-sectional questionnaire that included 14 Likert-scale items adopted from Saeheng (2017) to gather data from the participants. The questionnaire included demographic information, such as academic year, occupation status and gender. It took the respondents around fifteen minutes to complete the survey. As for the reliability measurement, the alpha coefficient for the whole questionnaire was calculated and was found to be 0.912; this can be regarded as a good result in terms of reliability. In addition, the validity of the questionnaire was checked by a panel of experts in the field. SPSS software version 22 was used for the analysis of the data.

\section{Findings}

\subsection{Findings of the First Research Question}

The first research question asked about the students' perceptions of a reading comprehension course delivered through e-learning sessions. The researchers used a cross-sectional questionnaire for data collection. Descriptive statistics were used, and means and standard deviations were calculated, as presented in Table 2.

Table-2. Students' perceptions of a reading comprehension course delivered through e-learning sessions.

\begin{tabular}{|c|c|c|c|}
\hline \multicolumn{2}{|c|}{ No. Items } & \multirow{2}{*}{$\frac{\text { Mean }}{3.99}$} & \multirow{2}{*}{$\frac{\text { SD }}{1.08}$} \\
\hline$\overline{1-}$ & Online sessions create an independent learning atmosphere. & & \\
\hline $2-$ & I studied online materials before coming to SEU university. & 2.41 & 1.26 \\
\hline $3-$ & Online sessions are more fun than traditional classes. & 3.69 & 1.20 \\
\hline $4-$ & Students gain more academic knowledge through online sessions. & 3.77 & 1.08 \\
\hline $5-$ & Students enjoy learning reading comprehension strategies through online sessions. & 3.83 & 1.01 \\
\hline $6-$ & Online sessions are suitable for the English Reading Comprehension Development course. & 3.82 & 1.02 \\
\hline $7-$ & Traditional learning is suitable for the English Reading Comprehension Development course. & 2.34 & 1.13 \\
\hline $8-$ & Students like to practice reading comprehension strategies during online sessions. & 3.84 & 1.20 \\
\hline $9-$ & Online sessions motivate students to develop different reading comprehension strategies. & 3.54 & 1.26 \\
\hline $10-$ & $\begin{array}{l}\text { Practising reading comprehension strategies such as skimming and scanning is more appropriate } \\
\text { during online sessions. }\end{array}$ & 3.72 & 1.15 \\
\hline $11-$ & $\begin{array}{l}\text { Practising reading comprehension strategies such as skimming and scanning is more appropriate } \\
\text { during traditional classes. }\end{array}$ & 2.24 & 1.22 \\
\hline $12-$ & $\begin{array}{l}\text { Students can understand more details when practicing reading comprehension strategies during } \\
\text { online sessions. }\end{array}$ & 3.81 & 1.10 \\
\hline $13-$ & In online sessions, students can easily identify the main ideas of the reading comprehension passage. & 3.77 & 1.08 \\
\hline$\overline{14-}$ & Online sessions facilitate the level of difficulty of any passage. & 3.77 & 1.15 \\
\hline
\end{tabular}

It is important to note that the aim of presenting items 1,2, 3, 4, 5, 6, 8, 9, 10, 12, 13, and 14 was to highlight the significance of online sessions in the reading comprehension development course. The findings showed that the mean of the respondents ranged between 2.41 and 3.99 (out of 5), meaning that most of the participants agreed that online sessions are able to enhance the development of their reading comprehension skill when virtually attending the reading comprehension course. It should be noted that some items focused specifically on the significance of online sessions in improving the reading comprehension skill. For example, item $12(\mathrm{M}=3.81 ; \mathrm{SD}=1.10)$ indicated that most of the participants agreed that they can understand more details when practicing reading comprehension strategies during online sessions. Item $9(\mathrm{M}=3.54 ; \mathrm{SD}=1.26)$ indicated that most of the participants believed that online sessions motivate students to develop different reading comprehension strategies. The responses to item 13 $(\mathrm{M}=3.77 ; \mathrm{SD}=1.08)$ indicated that the majority of the participants agreed that in online sessions, students can easily identify the main ideas of the reading comprehension passage. Item $14(\mathrm{M}=3.77 ; \mathrm{SD}=1.15)$ showed that online sessions facilitate the level of difficulty of any passage. As for the appropriateness of the use of online sessions to develop the reading comprehension skill, item $1(\mathrm{M}=3.99 ; \mathrm{SD}=1.08)$ showed that online sessions create an atmosphere conducive to independent learning. In addition, item $4(\mathrm{M}=3.77 ; \mathrm{SD}=1.08)$ indicated that most of the participants agreed that they gain more academic knowledge during online sessions. Item 10 ( $\mathrm{M}=3.72$; $\mathrm{SD}=1.15$ ) indicated that practicing reading comprehension strategies such as skimming and scanning was deemed more appropriate during online sessions.

In comparison with tradional classes, item $3(\mathrm{M}=3.69 ; \mathrm{SD}=1.20)$ indicated that most respondents agreed that online sessions are more fun than traditional classes. It is interesting to note that item $2(\mathrm{M}=2.41 ; \mathrm{SD}=1.26)$ reported that a moderate number of the participants had studied online materials before coming to SEU. Concerning the other items that focused on highlighting the appropriateness of traditional classes in the development of the reading comprehension skill, the respondents indicated that traditional learning is suitable for learning within the English Reading Comprehension Development course, as indicated by item 7 (M=2.34; $\mathrm{SD}=1.13)$. Additionally, item $11(\mathrm{M}=2.24 ; \mathrm{SD}=1.22)$ reported that practising reading comprehension strategies such as skimming and scanning was deemed more appropriate during traditional classes. It should be noted that the purpose of including such items $(7,11)$ was to ensure that the participants did not select their responses randomly.

\subsection{Findings of the Second Research Question}

On the other hand, the second research question asked whether there is a significant difference between EFL university students' perceptions of the reading comprehension development course delivered through e-learning sessions according to their gender or academic year. To answer this particular question, t-test analyses for gender and one-way ANOVA analyses for academic status were employed to find out whether there was a significant difference between the variables. Table 3 shows the effect of gender on the EFL students' perceptions of reading comprehension development by utilizing an independent sample t-test. The results of the $t$-test revealed a significant difference between male and female EFL students' perceptions. Thus, gender has a remarkable effect on students' perceptions, with the significant p-value $=.000$. 
Table-3. The effect of gender on EFL students' perceptions of reading comprehension development using an independent sample t-test.

\begin{tabular}{l|c|c|c|c|c|c}
\hline (Items 1-14) & Gender & N & Mean & SD & t & p \\
\hline $\begin{array}{l}\text { Students' perceptions of the reading comprehension } \\
\text { development course delivered through e-learning sessions }\end{array}$ & Male & 42 & 43.60 & 9.22 & -3.66 & 0.000 \\
\cline { 2 - 17 } & Female & 98 & 50.69 & 10.98 & &
\end{tabular}

development course delivered through e-learning sessions

Note: $* \mathrm{p}<0.05$.

The analysis of Variance (ANOVA) was used to determine whether there is a significant difference among EFL students' perceptions on the basis of their academic year. Table 4 depicts the results of the ANOVA concerning students' perceptions of reading comprehension development in connection with their academic year. According to Table 4, the difference between EFL students' perceptions according to their academic year is significant, since the p-value is .000.

Table-4. ANOVA for EFL students' perceptions and their academic years

\begin{tabular}{l|c|c|c|c|c|c}
\hline Items 1-14) & Year & $\mathbf{N}$ & Mean & SD & F & P \\
\hline Students' perceptions of the reading comprehension & Freshman & 100 & 46.22 & 11.96 & 8.94 & 0.000 \\
\cline { 2 - 7 } $\begin{array}{l}\text { development course delivered through e-learning } \\
\text { sessions }\end{array}$ & Junior & 30 & 54.60 & 2.63 & & \\
\cline { 2 - 7 } & Senior & 10 & 53.90 & 6.47 & & \\
\cline { 2 - 7 } & Total & 140 & 48.56 & 10.95 & & \\
\hline
\end{tabular}

Note: $* p<0.05$

In short, the independent sample t-test and the One-Way ANOVA show significant differences between EFL university students' perceptions of reading comprehension development according to their gender and academic year. Such results indicate that EFL university students' perceptions are influenced by the indicated variables, namely gender and academic year.

\section{Discussion}

\subsection{Discussion of the First Research Question}

This research was designed to examine EFL university students' perception of the reading comprehension development course delivered through e-learning sessions at the Saudi Electronic University and to investigate whether their perception is influenced by the dependent variables of gender and academic year.

As for the first research question, the salient aspects of the significance of reading comprehension development delivered through e-learning sessions have been noticeably highlighted in items 1, 2, 3, 4, 5, 6, 8, 9, 10, 12, 13, and 14. The results of these items suggest that EFL university students recognize the benefits and significance of online sessions in enhancing their reading comprehension development. For instance, items 9, 12, 13, and 14 highlighted the belief that online sessions motivate students to develop different reading comprehension strategies as well as facilitating the difficulty of the reading selection. This finding is consistent with the research conducted by Radia (2019) and Saeheng (2017). Saeheng (2017) argued that "e-learning and blended learning would be effective teaching delivery methods to motivate them to practice their English reading comprehension skill and their autonomous learning" (p. 15). This indicates that online sessions enhance learning within a reading comprehension development course. EFL university students will find no hardship in improving their reading comprehension skills in a course that incudes online sessions.

As for items 1, 3, 4, 5, and 10, students generally reported a high level of appropriateness of the use of online sessions in developing the reading comprehension skill. It is interesting to note that this finding is in line with the results of Nikolova, Nikolov, and Kovatcheva (2005). Based on students' overall perception, Nikolova et al. (2005) claimed that online courses provide an appropriate method of learning. This implies that many students find it more convenient to practice reading comprehension skills in online sessions (Behjat et al., 2012). It should be noted that items (7 and 11) represent the appropriateness of traditional classes for enhancing reading comprehension skills. However, the EFL university students' responses to these items were at the lower end of the scale. Thus, due to this remarkable level of acceptance of the trend towards learning reading comprehension skills through elearning sessions, it seems that the majority of EFL university students do enjoy learning reading comprehension and its strategies through e-learning.

\subsection{Discussion of the Second Research Question}

The findings of the independent variables in this research, namely gender and academic year, showed statistically significant differences concerning their impact on the EFL university students' perceptions.

\subsubsection{Gender}

The findings indicate that gender causes a significant difference in the students' perceptions of the reading comprehension development course delivered through e-learning sessions. This indicates that gender had an impact on the EFL university students' perceptions. The significant difference was noted in favor of female students' perceptions $(t=-3.66, \mathrm{p}<.05)$. This can be attributed to the fact that there are more females $(70.0 \%)$ than males in the English Language and Translation major at SEU. This result is in harmony with previous research (González-Gómez, Guardiola, Rodríguez, \& Alonso, 2012; Mahfouz \& Ihmeideh, 2009; Zhan, 2018). GonzálezGómez et al. (2012) found that female students report a higher level of satisfaction in relation to e-learning compared to male students. They also noted that this finding contradicts previous studies that support the claim that male students are more satisfied with e-learning than female students.

\subsubsection{Students' Academic Year}

Regarding the students' academic year, the demographic data accentuated that $71.4 \%$ of the participants were freshmen (level 3\&4). This implies that the results of this research are probably affected by this category representing the academic years. The findings showed that there was a significant difference in the EFL university 
students' perceptions of the reading comprehension development course based on the academic year variable $(\mathrm{f}=8.94, \mathrm{p}<.05)$. This can be attributed to the large number of university students represented by the category of freshman $(71.4 \%)$ participating in this study. This result is supported by multiple studies in which significant differences were found relating to students' academic year (e.g., (Bataineh \& Baniabdelrahman, 2006; Dakeev, Mazumder, Yildiz, Baltaci, \& Mamadiev, 2015; Mahfouz \& Ihmeideh, 2009)).

\section{Conclusion, Recommendations, and Implications}

E-learning plays a significant role in transforming traditional learning and enhancing English language teaching in Saudi Arabia. The review of the previous literature showed that there is a need to investigate students' perceptions of e-learning in Saudi Arabia, especially in the field of EFL. This quantitative study examined the perceptions of 140 undergraduate EFL students toward the development of the reading comprehension skill through e-learning sessions at SEU. The study utilized a cross-sectional questionnaire to collect the data. Descriptive statistics, independent sample paired t-tests and a one-way ANOVA were used to analyze the data. The findings showed that the participants had positive attitudes toward the development of the reading comprehension skill through e-learning sessions. The participants appreciated the role of online sessions in enhancing their reading comprehension skills and facilitating the level of difficulty of any reading passage. They reported that they were able to understand more details and identify the main ideas of the reading passage more easily. The majority agreed that practicing reading comprehension strategies such as skimming, and scanning was more appropriate to online sessions. E-learning helped these students to feel more motivated and create an atmosphere conducive to independent learning. Also, the study showed that the two variables of gender and students' academic year had a significant impact on the participants' perceptions. Female students were more satisfied with e-learning than males, and freshmen were less satisfied than upperclassmen.

With the rapid growth of e-learning in Saudi Arabia, and the need to increase the provision of online learning programs in universities, developing well-structured courses for e-learning implementation is vital. According to the positive views of the participants in this study, the use of e-learning withing a well-designed reading comprehension development course is highly recommended. This course must, of course, be managed and supported sufficiently to succeed and achieve the anticipated outcomes.

It is also recommended that students' technical skills be assessed before enrolment in the course. Training should be offered to students who lack any required skills. Orientations to e-learning settings, with more consideration of online tools, applications, and technical support, should be provided for both students and instructors. With respect to lecturers, it is crucial that they maintain sufficient teaching and IT skills. This new learning environment demands clear guidelines from lecturers, including a detailed syllabus and rubrics. The lecturer must be able to manage online interaction and encourage student motivation and engagement.

Decision-makers and departments must act upon instructors and students' opinions on the importance and effectiveness of e-learning. A thorough, periodical evaluation that investigates students' and lecturers' perceptions and recommendations should be implemented for the development and improvement of every course.

\section{References}

Al-Asmari, A., \& Khan, S. (2014). E-learning in Saudi Arabia: Past, present and future. Near and Middle Eastern Journal of Research in Education, 2(1), 2-11.

Al-Fahad, A. F. (2010). The learners' satisfaction toward online e-learning implemented in the college of applied studies and community service, King Saud University, Saudi Arabia: Can e-Learning replace the conventional system of education? Turkish Online Journal of Distance Education, $11(2), 61-72$.

Al-Harbi, K. A.-S. (2011). E-learning in the Saudi tertiary education: Potential and challenges. Applied Computing and Informatics, 9(1), $31-46$. Available at: https://doi.org/10.1016/j.aci.2010.03.002.

Al-Khalifa, H. S. (2010). E-learning and ICT integration in colleges and universities in Saudi Arabia. ELearn, 201O(3), 1-4.

Al-Mubireek, S. (2019). E-learning in the english classroom: Comparing two e-learning platforms impacting preparatory year students' language learning. CALL-EJ, 2O(2), 19-37.

Al-Nuaim, H. A. (2012). The use of virtual classrooms in e-learning: A case study in King Abdulaziz University, Saudi Arabia. E-Learning and Digital Media, 9(2), $211-222$.

Algahtani, A. (2011). Evaluating the effectiveness of the e-learning experience in some universities in Saudi Arabia from male students' perceptions. Doctoral Dissertation, Durham University.

Alhumsi, M. H. (2021). The issue of the reading skills in medical schools during the coronavirus pandemic. Mextesol Journal, 45(3), 1-7.

Alhumsi, M. H., \& Alshaye, R. A. (2021). Applying technology acceptance model to Gauge University students' perceptions of using blackboard in learning academic writing. Knowledge Management $\Xi^{2}$ E-Learning: An International Journal, 13(3), $316-333$.

Aljaber, A. (2018). E-learning policy in Saudi Arabia: Challenges and successes. Research in Comparative and International Education, 13(1), 176-194. Available at: https://doi.org/10.1177/1745499918764147.

Alkhalaf, S., Drew, S., \& Alhussain, T. (2012). Assessing the impact of e-learning systems on learners: A survey study in the KSA. ProcediaSocial and Behavioral Sciences, 47, 98-104. Available at: https://doi.org/10.1016/j.sbspro.2012.06.620.

Alkhalaf, S., Nguyen, J., Nguyen, A., \& Drew, S. (2013). Online learner satisfaction and collaborative learning: Evidence from Saudi Arabia. International Journal of Information and Communication Technology Education (IJICTE), 9(2), 66-78. Available at: https://doi.org/10.4018/jicte.2013040106.

Alsayyar, A., \& Almakki, R. (2021). The impact of augmented reality on E-learning systems in Saudi Arabia universities. Computer and Information Science, 14(2), 1-50. Available at: https://doi.org/10.5539/cis.v14n2p50.

Alubthne, F. (2018). Exploring the quality needs of Saudi electronic University students: A learner perspective. Doctoral Dissertation.

Alyousef, H. S. (2005). Teaching reading comprehension to ESL/EFL learners. The Reading Matrix, 5(2), 143-154.

Anas, A. (2020). Perceptions of Saudi students to blended learning environments at the University of Bisha, Saudi Arabia. Arab World English Journal, 261-277. Available at: https://dx.doi.org/10.24093/awej/call6.17.

Bataineh, R., \& Baniabdelrahman, A. (2006). Jordanian EFL students' perceptions of their computer literacy. International Journal of Education and Development using ICT, 2(2), 35-50.

Behjat, F., Yamini, M., \& Bagheri, M. S. (2012). Blended learning: A ubiquitous learning environment for reading comprehension. International Journal of English Linguistics, 2(1), 97-106. Available at: https://doi.org/10.5539/ijel.v2n 1p97.

Caner, M. (2012). The definition of blended learning in higher education. In P. Anastasiades (Ed.), Blended learning environments for adults: Evaluations and frameworks (pp. 19-34). Hershey, PA, USA: IGI Global.

Creswell, J. W. (2012). Qualitative inquiry \& research design: Choosing among five approaches (4th ed.). Thousand Oaks, CA: Sage.

Dakeev, U., Mazumder, Q. H., Yildiz, F., Baltaci, K., \& Mamadiev, B. (2015). Motivation and learning strategies of students in Kyrgyzstan. Paper presented at the 2015 ASEE Annual Conference \& Exposition. 
Dubin, F., \& Bycina, D. (1991). Academic reading and ESL/EFL teacher. In M. Celce Murcia (Ed.), Teaching English as a second or foreign language (pp. 195-215). Boston, MA: Heinle \& Heinle Publishers.

Dwiastuty, N., Susilawati, \& Sulhan, M. (2018). The using of readutainment as e-learning to improve students' reading comprehension skill. MATEC Web of Conferences, 154, 03007. Available at: https://doi.org/10.1051/matecconf/201815403007.

Farooq, M. U., \& Javid, C. Z. (2012). Attitude of students towards E-learning: A study of English language learners at Taif University English Language Centre. NUML Journal of Critical Inquiry, 1O(2), 17-28.

Flórez, G. É., Pineda, J. E., \& Marín, G. N. (2012). EFL students' perceptions about a web-based English reading comprehension course. Profile Issues in Teachers Professional Development, 14(2), 113-129.

Gawad, A., \& Al-Masaud, K. (2014). Impediments of activating e-learning in higher education institutions in Saudi Arabia. International Journal of Advanced Computer Science and Applications, 5(4), 12-18. Available at: https://doi.org/10.14569/ijacsa.2014.050403.

González-Gómez, F., Guardiola, J., Rodríguez, Ó. M., \& Alonso, M. Á. M. (2012). Gender differences in e-learning satisfaction. Computers छ̋ Education, 58(1), 283-290.

Grabe, W., \& Stoller, F. (2002). Teaching and researching reading. Harlow, Essex: Pearson Education Limited.

Harasim, L. (2012). Learning theory and online technologies. New York: Routledge/Taylor \& Francis.

Larkin, H. E. (2010). But they won't come to lectures: The impact of audio recorded lectures on student experience and attendance. Australasian Journal of Educational Technology, 26(2), 238-249. Available at: https://doi.org/10.14742/ajet.1093.

Liaw, S. S., \& Huang, H. M. (2011). A study of investigating learners' attitudes toward e-learning. Paper presented at the 5th International Conference on Distance Learning and Education.

Mahfouz, S. M., \& Ihmeideh, F. M. (2009). Attitudes of Jordanian university students towards using online chat discourse with native speakers of English for improving their language proficiency. Computer Assisted Language Learning, 22(3), 207-227. Available at: https://doi.org/10.1080/09588220902920151.

Mirza, A. (2007). Utilizing distance learning technologies to deliver courses in a segregated educational environment. Paper presented at the World Conference on Educational Multimedia, Hypermedia and Telecommunications, Vancouver, Canada.

Muñoz, M., Jorge Hugo, \& González, M. A. (2010). Teaching reading comprehension in English in a distance web-based course: New roles for teachers. Profile Issues in TeachersProfessional Development, 12(2), 69-85.

Mutambik, I. (2018). The role of e-learning in studying English as a foreign language in Saudi Arabia: Students' and teachers' perspectives. English Language Teaching, $11(5), 74$. Available at: https://doi.org/10.5539/elt.v 1 1n5p74.

Naveed, Q. N., Muhammed, A., Sanober, S., Qureshi, M. R., \& Shah, A. (2017). Barriers effecting successful implementation of e-learning in Saudi Arabian universities. International Journal of Emerging Technologies in Learning, 12(6), 94-107. Available at: https://doi.org/10.3991/ijet.v12i06.7003.

Nikolova, I., Nikolov, R., \& Kovatcheva, E. (2005). E-learning for e-learning: Reflection on teacher and student experiences in an e-learning course. Paper presented at the 2 nd Balkan Conference on Informatics.

Oraif, I., \& Elyas, T. (2021). The impact of COVID-19 on learning: Investigating EFL learners' engagement in online courses in Saudi Arabia. Education Sciences, 11 (3), 99. Available at: https://doi.org/10.3390/educsci 11030099.

Oyaid, A. (2009). Education policy in Saudi Arabia and its relation to secondary school teachers. ICT use, perceptions, and views of the future of ICT in education. Doctoral Dissertation, University of Exeter, UK.

Picciano, A. G. (2017). Theories and frameworks for online education: Seeking an integrated model. Online Learning, 21(3), 166-190. Available at: https://doi.org/10.24059/olj.v21i3.1225.

Radia, B. (2019). Approaching a reading course via moodle-based blended learning: Efl learners' insights. Modern Journal of Language Teaching Methods (MJLTM), 9(11), 1-12.

Rodrigues, H., Almeida, F., Figueiredo, V., \& Lopes, S. L. (2019). Tracking e-learning through published papers: A systematic review. Computers Eं Education, 136, 87-98. Available at: https://doi.org/10.1016/j.compedu.2019.03.007.

Saeheng, P. (2017). A study of e-learning, blended learning, and traditional teaching methods to motivate autonomous learning in English reading comprehension of Thais learners. Indonesian Journal of English Language Teaching and Applied Linguistics, 2(1), 1-20. Available at: https://doi.org/10.21093/ijeltal.v2i1.36.

Sebnmen, K. (2015). Investigation of students' Attitudes towards e-learning interms of different variables. Journal of Educational Research and Reviews, $10(1), 81-91$.

Sun, P.-C., Tsai, R. J., Finger, G., Chen, Y.-Y., \& Yeh, D. (2008). What drives a successful e-Learning? An empirical investigation of the critical factors influencing learner satisfaction. Computers \& Education, 50(4), 1183-1202. Available at: https://doi.org/10.1016/j.compedu.2006.11.007.

Suri, G., \& Sharma, S. (2013). The impact of gender on attitude towards computer technology and e-learning: An exploratory study of Punjab University, India. International Journal of Engineering Research, 2(2), 132-136.

Valverde-Berrocoso, J., Garrido-Arroyo, M. D., Burgos-Videla, C., \& Morales-Cevallos, M. B. (2020). Trends in educational research about elearning: A systematic literature review (2009-2018). Sustainability, 12(2), 5153. Available at: https://doi.org/10.3390/su12125153.

Yamani, H. A. (2014). E-learning in Saudi Arabia: Challenges and opportunities. Journal of Information Technology and Application in Education, $3(4), 169-172$. Available at: https://doi.org/10.14355.

Yang, Y. F. (2012). Blended learning for college students with English reading difficulties. Computer Assisted Language Learning, 25(5), 30-34. Available at: https://doi.org/10.1080/09588221.2011.597767.

Zabadi, A. M., \& Al-Alawi, A. H. (2016). University students' attitudes towards e-learning: University of Business \& Technology (UBT)Saudi Arabia-Jeddah: A case study. International Journal of Business and Management, 11(6), 286. Available at: https://doi.org/10.5539/ijbm.v1 1n6p286.

Zahedi, Z., \& Tabatabaei, O. (2015). The effect of blended teaching on reading strategy use by Iranian EFL learners. International Journal of Foreign Language Teaching and Research, 3(11), 25-38.

Zarei, A. A., \& Amani, M. A. (2018). The effect of online learning tools on L2 reading comprehension and vocabulary learning. Teaching English as a Second Language (Formerly Journal of Teaching Language Skills), 37(3), 21 1-238.

Zhan, Y. (2018). Chinese high school students' test preparation strategies for a high-stakes computer-based English listening and speaking test: Roles of achievement goals. The Asian EFL Journal Quarterly, 20(12.1), 99-125. 